DOI: $10.22559 /$ folklor.1093

folklor/edebiyat, cilt: 25 , sayl: 100, 2019/4

\title{
Efsanevî Bir Kadın Ermiş ve Acele Bacı Helvası Ritüeli
}

\section{A Legendary Saint and the Rituel of Acele Baci's Halvah}

\section{Seval Kasımoğlu* Şule Berber**}

$\ddot{\mathbf{O} z}$

Ritüeller; toplumun kabul, inanç ve değerlerini sunan eylemlerdir. Bu inanç, kabul ve değerler ritüelin varlığını devam ettirmesi ve onaylanması adına oldukça önemlidir. Özellikle bir mit ya da efsane ile desteklenen ritüeller, toplumun kültürel kodlarını sembolik bir dille anlatan metinler olarak okunabilir. Bu metinlerin toplum tarafından kabullenilmeleri taşıdıkları işlevlerle de ilgilidir. Bu tür ritüellerden biri, "Hacca Giden Ağasına Helva Götürme" motifli bir efsane örneği ile desteklenen Acele Bacı Helvası Ritüeli'dir. Bu ritüel, Mersin, Eskişehir, Bursa, Adana, Aydın, İzmir gibi pek çok şehirde uygulanmaktadır. Bu çalışmada bir efsaneyle desteklenen ve günümüzde yaşatılmaya devam edilen Acele Bacı/Helvacı Bacı ritüeli hakkında bilgi verilirken, ritüelin hangi sınıflandırma başlığı altında incelenebileceği ve hangi işlevleri gerçekleştirdiği sorusuna da cevap aranmaya çalışılacaktır. Bu amaçla çalışmada Acele Bacı Helvası ritüeli sınıflandırılırken Lauri Honko'nun ritüellerle ilgili yaptı̆̆ tasnifi esas alınmıştır. Ritüelin işlevi konusunda ise Özkul Çobanoğlu'nun Hıdırellez ve Nevruz bayramlarını incelemek üzere ortaya koyduğu dört işlev esas alınmıştır. Çobanoğlu bu işlevleri ortaya koyarken William

Çankırı Karatekin Üniversitesi, Türk Dili ve Edebiyatı Bölümü, sevalkasimoglu@karatekin.edu.tr, sevalkasimoglu@gmail.com, ORCID ID 0000-0002-2706-9492.

** Çankırı Karatekin Üniversitesi, Türk Dili ve Edebiyatı Bölümü, elusberber88@hotmail.com 
Bascom'un folklorun dört işlevi ve Emile Durkheim toplumsal ritüeller konusunda belirlediği dört işlevinin bir sentezini yapmıştır.

Anahtar sözcükler: Acele Bacı, efsane, helva, işlev, ritüel

\begin{abstract}
Rituals are deeds that represent the acceptance, beliefs and values of a society. These beliefs, acceptances and values are important for the ritual to maintain its existence and become approved. Rituals particularly assisted with a myth or a legend can be read as texts with a symbolic narration of a society's cultural codes. The acceptance of these texts are associated with their functions too. One of these rituals is "Acele Bac1 Helvası (Hasty Sister's Halva)" Ritual, to be reviewed under the title of legends with "Taking Halva to the Soon-to-become-Pilgrim Husband" motive. Assisted with a legend known by the same name, is being practised in several towns including Mersin, Eskişehir, Bursa, Adana, Aydın, Izmir. This study will be trying to provide information about "Acele Bac1/Helvacı Bacı" ritual, assisted with a legend and still being practised today, while also looking to identify the categorization and functions of the ritual. For this purpose, the classification of the rituals of the "Acele Bac1/Helvacı Bacı" is based on the classification of Lauri Honko on the rituals. Regarding the function of the ritual, four functions Özkul Çobanoğlu put forward to examine Hidırellez and Nevruz feasts are based on. While demonstrating these functions, Çobanoğlu synthesized William Bascom's four functions of folklore and Emile Durkheim's synthesis of four functions on social rituals.
\end{abstract}

Keywords: Acele Bact, function, halva, myth, ritual

\title{
Efsaneler /Mitler ve ritüeller
}

Farklı disiplinlerin çalışma alanı içinde yer alan ritüeller, gruplar ya da bireyler tarafından belli/belirsiz aralıklarla gerçekleştirilen sembolik eylemlerdir. Ritüeller konusunda en önemli çalışmalardan biri Arnold Van Gennep'e aittir. Gennep, ritüelleri incelerken geçiş ritüelleri terimine vurgu yapar. 1909 yılında yayımlanan Geçiş Ritüelleri (1909) isimli (lesrites de passage) eserinde üç aşamadan oluşan (ayrılma, eşik ve dönüş) geçiş ritüellerinin "bireyin çeşitli boyutlardaki 'sınırı geçme' olayını ve toplum içerisindeki statüsünün değişimini anlatan ve belirli kurallara bağlanan geleneksel ve dinsel törenler” olduğunu söylemektedir (Ozan, 2011: 73).

Ritüeller konusunda yapılan çalışmalardan biri Emile Durkheim'e ${ }^{1}$ aittir. Ritüellerin genel olarak negatif ve pozitif olarak ikiye ayrılabileceği üzerinde duran Durkheim'a göre negatif ritüeller, olumsuz ve negatif durumların oluşmasını önlemek amacıyla gerçekleştirildiğinden kaçınma ve yasaklamaları içermektedir. Bu tarz ritüeller kişilere yerine getirmeleri gereken kuralları hatırlatmazlar bunun yerine yapılmaması gerekenleri yasaklarlar. Negatif ritüellerin en önemli özelliklerinden biri de pozitif ritüller için bir ön koşul oluşturmasıdır. Birey, ancak negatif ritüellerle din dışı unsurlardan arınıp kutsal olana yaklaşabilir. Pozitif 
ritüeller ise bireyin kutsal olana daha fazla yaklaşması ve kendi tekamülünü sağlaması için yapılması gerekenleri içeren ritüellerdir (Durkheim, 2005: 358).

Ritüeller konusunda diğer bir önemli çalışma Victor Turner'a aittir. Turner, Gennep'in üç aşamalı şemasının özellikle eşik kısmı üzerinde durmuştur. Turner'in bakış açısıyla eşik döneminin en önemli işlevi toplum hayatı için bir sübap görevi görmesidir. İkili karşıtlıklar ilkesi üzerinden ritüeldeki sembolleri inceleyen Turner'e göre ritüeller "iklime bağlı mevsimsel/sezonluk olabilecekleri gibi, yaşamsal geçiş, dönüşüm ve krizleri de kapsayabilecek" (Akın, 2017: 52) bireysel ya da toplumsal bir niteliğe sahiptir.

Ritüeller konusunda bir diğer dikkat çeken çalışma Finli, karşılaştırmalı din ve folklor çalışmaları profesörü olan Lauri Honko tarafından yapılmıştır. Honko ritüelleri,

1. Geçiş Ritleri (insanın yaşamında açılan yeni bir dönemi vurgulayan ritler)

2. Takvimsel Ritler

3. Kriz Ritleri (Honko, 2006: 131) olarak üç kısımda ele alan bir sınıflandırma öne sürmektedir.

Ritüelle ilgili en tartışmalı konularından biri, ritüelin mit ya da efsanelerle olan ilişkisidir. Fuzuli Bayat, efsanelerle mitler arasındaki yakınlık konusunda "özellikle ritüel içerikli efsanelerle ritüeli anlatan mit arasında fark yok gibidir" (Bayat, 2010: 119) demektedir. Bahattin Ögel ise bu yakınlığ 1 "efsaneler (mythes), bir milletin mitolojisinin canlı ve yaşayan varlıkları gibidirler” (Ögel, 2010: VI) sözleri ile açıklamaktadır. Bayat'ın ve Ögel'in yukarıdaki sözleri ile ritüelle ilgili yapılan çalışmalarda efsane ve mitlerin birbiri yerine kullanılması ${ }^{2}$ doğrultusunda bu makalede de ritüellerin efsane ile bağlantısı konusu ele alınırken ritüel-mit bağlantısına yer veren açıklamalardan yararlanılmıştır.

Mitin diğer bir bağlantısının tartışıldığı türlerden biri de ritüellerdir. "Ritüel canlı mitolojidir" diyen Joseph Campbell (1995: 123) mit ile ritüeli birbirinin eşdeğeri olarak ele almaktadır. Benzer bir yakınlığa Metin And da "Ritüel bir bakıma Mithos'un ikiz kardeşidir" (And, 2008: 27) diyerek dikkat çekmektedir. And bu ilişki konusunda şunları söylemektedir:

Eski uygarlıkların günümüze kalan yazılı metinleri, ritüelleri anlatır. Bunlar bir eylemler dizisi olup birtakım yetkili kişilerin kesin ve kuralına uygun bir biçimde uyguladıkları eylemlerdir. Bunlar insanoğlunu çevreleyen güçlere karşı toplumun iyiliği için yapılan eylemlerdir. Bu eyleme Yunanlılar dromenon diyorlardı. Bunlar yalnız eylemler dizisi olmayıp sözler, ezgiler ve büyüsel sözler de içerirdi. Bunun söz yan ise muthos ya da mithos 'tur. Bu ritüellerde mithos bu eylemin öyküsünü sözle anlatır. Bir başka deyişle birisi simgesel söz, öteki simgesel eylemdir (And, 2008: 27).

Yukarıda belirtilenler bağlamında mit/efsane ve ritüel ilişkisine bakıldığında denilebilir ki bu iki önemli tür, birbirinin aynı olmayan ancak paralel bir işleyişe sahip çizgide yer almaktadır. Bir ritüele bağlı olarak anlatılan mit/efsane, William R. Bascom’un dediği gibi, "kültürün onaylanması ve ritüelleri gözlemleyen ve icra edenlerin ritüellerinin ve kurumlarının doğrulanmasını” (Bascom, 2010: 140) sağlamaktadır. Bunun yanında ritüelin amacını ve tarihini anlatan mitik anlatılar, ritüellerin toplum içinde daha fazla ayakta kalmasını sağladığı gibi onun meşruiyet zeminini de sağlamlaştırmaktadır. 


\section{Efsanelerde hacca giden ağasına helva götürme motifi}

Efsaneler, çok çeşitliliğe ve yayılma gücüne sahip olan sözlü türlerden biridir. Bu türün çeşitliliği, içerisindeki motiflerin çeşitliliğiyle paralellik göstermiştir. Türkiye'de örneğine en fazla rastlanılan efsane motiflerinden birini Ali Berat Alptekin "Hacca Giden Ağasına Helva Götürme Motif”” olarak adlandırmaktadır (Alptekin, 2012: 126). Bu motifin yer aldığı anlatı genellikle ağ, bey, tüccar gibi maddî durumu iyi bir kişi ile onun yanında çalışan hizmetlinin anekdotunu içerir.

İlk örnekleri Hoca Ahmet Yesevi ve Hacı Bektaş Veli Velâyetnamesi'nde görülen bu efsanenin Munzur Baba (Tunceli-Ovacık), Mehmet Dede (Ağrı), Ökkeş Dede (Kahramanmaraş), Memik Dede (Gaziantep), Lokman Dede (İzmir- Bergama), Hoca Yusuf (Malatya), Kara Fakı, Yüğrük Şahin (Sivas), Ali (Diyarbakır), Aliyar (Yozgat), Hacı Efraim Devletlü (Adana-Kozan), Fariğ Emine (Balıkesir- Mudurnu), Şeyh Bilecen (Gaziantep), Kıyan Dağı Efsanesi (Elbistan'ın Ozanya köyü), Hafız Ali (Kahramanmaraş), Hasan Dede (Kırıkkale) gibi Anadolu'nun pek çok yerinde farklılaşan örnekleri vardır. Bu motif temelde üç temel yapıdan oluşmaktadır:

1. Beyin, ağanın hacca gitmek istemesi

2. Ağanın/beyin eşinin yemek yapması ve yanlarında çalışan kişinin (kadın ya da erkek) bu yemeği hacca götürmesi

3. Ağanın/beyin hacdan dönüşü ve kendisine getirilen yemek kabının gösterilmesiyle hizmetlinin evliya olduğunun ortaya çıkışı.

Bu motifle ilgili çeşitlenmeler ise genellikle şu şekildedir:

1. Bu motifin barındığı pek çok efsanede hacca giden kişi, helvayı yapan kişinin eşidir. Yalnız, Kahramanmaraş'tan derlenen Hafız Ali efsanesinde hacca giden kişi ev sahibesinin erkek kardeşidir. Ona yiyecek götüren kişi ise aynı zamanda ablasının eşi olan Hafız Ali'dir.

2. Efsanenin farklı örneklerinde hacca giden kişinin mesleği genellikle tüccar, bey, ağa gibi çeşitlilik göstermektedir.

3. Hacca götürülen yiyecek farklı anlatılarda farklı şekillerde karşımıza çıkabilmektedir. Bunlar tatlı, çorba, yemek, içli köfte şeklinde çeşitlenebilir. Örneğin Hacı Bektaş ve Lokman Perende'nin efsanesinde şeyhin evinde pişi pişer. Karslı Keloğlan (helva); Kağızman'dan Hacı Kağızman (helva); Erzurum'dan Ahmet Baba (helva); Tunceli'den Munzur Baba (helva), Orta Anadolu'dan Hacı İbrahim Devletlü (yemek) ve Yuanis (pilav ya da mantı); Koçarlı'dan Bilal Dede (helva); Sungurlu'dan derlenen Ali Baz efsanesinde helva (Sakaoğlu, 1997: 181-182) pişirilir. Muğla'dan derlenen Çoban Evliya isimli efsanede ise çoban, patronu için hacca koyun yoğurdu ve süt götürür. Gaziantep'in Oğuzeli ilçesine bağlı, eski adı Şıhbilecen olan bugün ise Arslanlı olarak adlandırılan köyünde geçen efsanede Şeyh Bilecen'in hacdaki beye götürdüğü yiyecek, içli köftedir. Gaziantep'ten derlenen Memik Dede efsanesinde yine hacca götürülen yiyecek içli köftedir. Kahramanmaraş’tan derlenen Hafız Ali efsanesinde hacca köfte götürülür. 
4. Efsanelerde yiyeceğin taşındığı nesneler de farklılaşmaktadır. Bu nesneler bir tabak, tepsi, bakraç olabilmektedir. Şeyh Bilecen efsanesinde içli köftelerin götürüldüğü nesne bir mendildir. Hafız Ali efsanesinde bir tabak ve bir çanta yardımıyla köfteler hacca götürülür.

5. Efsanenin sonunda ağaya/beye yiyecek götüren ve keramet gösteren kişinin sırrı ortaya çıkar. Memik Dede efsanesinde sırrı ortaya çıkan Memik Dede, bastonunu toprağa vurunca ortadan kaybolur. Kıyan Dağı efsanesinde sırrı ortaya çıkan Kıyan, Kıyan dağına doğru kaçarak ortadan kaybolur. Kıyan'ın kaçtığı dağa Kıyan Dağı adı verilir. (Gönen, 2007: 174). Kayseri/Havatan Köyü'nde yer alan Hacı İbrahim Devletli efsanesinde bey, hacdan döndüğünde ermiş çobanı uyurken, hayvanları da dağılmış vaziyette bulduğunda kızar. Çoban hemen hayvanları toplamak için denizin üzerinde yürümeye başlar. Bey de onun bir ermiş olduğunu bu şekilde anlar.

Yukarıda çeşitli özellikleriyle üzerinde durulan "Hacca Giden Ağasına Helva Götürme Motifli" efsanelerden biri de Acele Bacı efsanesi olarak bilinmektedir. Bu efsanenin en önemli özelliği bir ritüele dayanmasıdır. Makalenin bu kısmında Acele Bacı hakkında kısa bir bilgi verilmesi gerekirse şunlar söylenilebilir:

Helvacı Bacı olarak da bilinen Acele Bacı, Bursa'nın Osmangazi şehrinde türbesi bulunan efsanevî bir figürdür. Bulgaristan'ın Filibe kasabasından Bursa'ya geldiği rivayet edilen Helvacı Bacı keramet gösteren Bursa evliyaları arasında yer almaktadır. Hakkında çok az bilgi bulunan Helvacı Bacı'nın mezarı, Tahtakale Veziri caddesinde, Pınarbaşı mezarlığına doğru çıkarken solda bulunan Helvacıoğlu Mescidi önündedir.

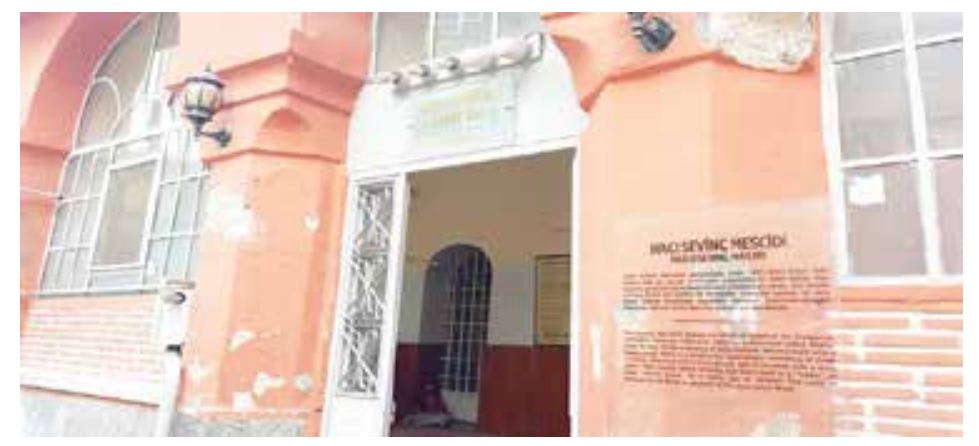

Efsaneye göre Helvacı Bacı, Hacı Sevinç Mescidi’ni yaptıran tüccarın evinde hizmetçidir. Mescid, inşaat halinde iken tüccar hacca gider. Bir gün tüccarın eşi evde helva pişirirken hizmetçi kıza "Efendim helvayı çok severdi” der. Bu söz üzerine, hizmetçi kız eline bir tabak alıp içine bir miktar helva koyduktan sonra "Ağız tadıyla bu helvayı yesin" der. Bu durumu gören kadın şaşırır ve hizmetçi kıza ne yaptığını sorar. Tüccarın, hacdan dönüşünde hizmetçi kızın helva koyduğu o tabak, eşyaları arasından çıkar. Bu durum, hizmetçi kızın kerameti olarak görülür ve bu olaydan sonra "Helvacı Bacı" olarak anılmaya başlanır. Vefat ettiğinde Hacı Sevinç Mescidi'nin batısına defnedilmiştir.

Acele Bacı Helvası ritüeli şu şekilde gerçekleşmektedir: Daha önce dileği kabul olan bir kişi, evinde iki rekât hacet namazı kıldıktan sonra hiç konuşmadan mutfağa geçer ve helva malzemelerini hazırlayarak misafirlerini bekler. Helvanın malzemeleri; irmik, isteğe göre 
sıvı yağ veya tereyağ, şeker, su veya tercihe göre su yerine süttür. Tercihen tarçın, ceviz veya fistık da kullanılabilir. Bu helva, misafirlerin gelmesinden sonra ritüelin gerçekleşeceği yerde pişirilir.

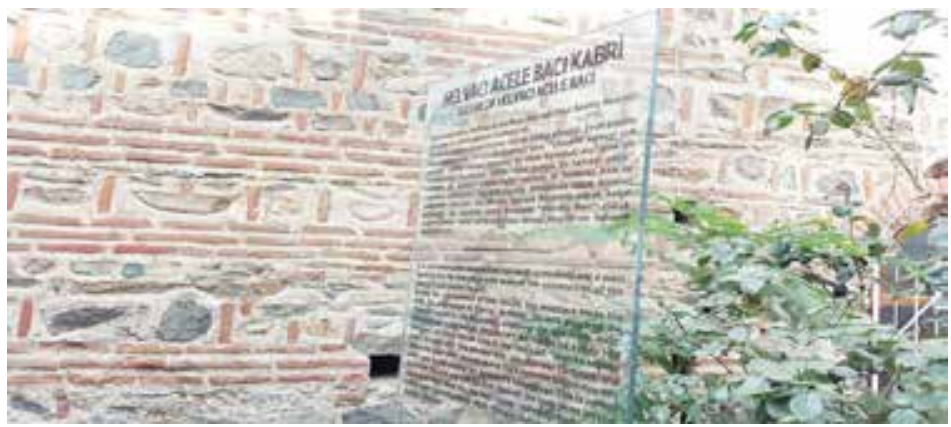

Ritüel başlamadan evvel katılımcılar abdest alır. Selâ ile birlikte kadınların toplandığı odaya küçük tüp ve helva malzemeleri getirilerek Kuran-1 Kerim okunmaya başlanır. Misafirler Kuran'1 takip ederken ev sahibi de helvayı kavurmaya başlar. Helva kavrulurken bir Fatiha üç İhlas okuduktan sonra “Allah'ım şükürler olsun dileğim kabul oldu, duamı bana eriştirdin" diye dua edilir. Daha sonra okunan sureler ve dualar başta peygamberler olmak üzere evliyaların ve Acele Bacının ruhuna bağışlanarak dilekler tekrar edilir.

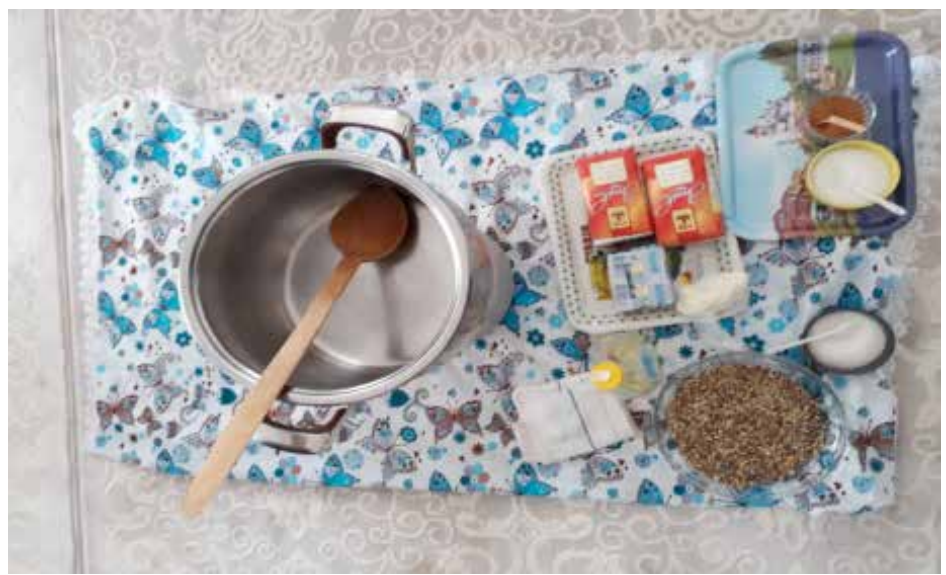

Ardından, gelen misafirler helvayı sırayla karıştırarak içlerinden kendi dileklerini söylerler. Dua süreci, selâ ile başlayıp öğle ezanına kadar sürmektedir. Ardından ezanın okunmasıyla dua süreci tamamlanır ve hazırlanan helvanın acilen tüketilmesi sağlanır. Katılan kişiler yanlarında alıp kendi evlerine helva götüremezler. Helvanın yapıldığ evde tüketilmesi gerekmektedir. Helvanın bir kısmı da duanın daha çabuk kabul olması için kuşlara yedirilir.

Bir sonraki ritüel, oradaki kişilerden birinin dileğinin kabulünün ardından onun evinde gerçekleşir. Daha sonra duası kabul olan kişi “benim Acele Bacı dileğim kabul oldu” diyerek komşularından, akrabalarından en az yedi kişiyi çağırarak bu ritüeli gerçekleştirir.

Acele Bacı ritüeli, en az yedi kadının katılımıyla gerçekleştirilen bir ritüeldir. Ritüelin yapısal özellikleri şu şekildedir: 


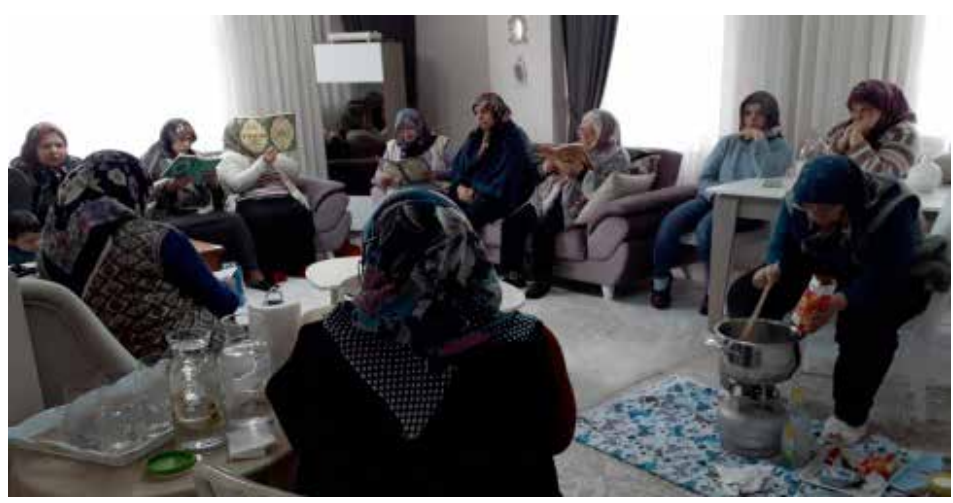

1. Acele Bacı ritüelinde, temelde isteklerin gerçekleştirilmesi amacı güdülmektedir. Ritüel, isteği gerçekleşen birinin evinde şükür etmek amacıyla düzenlenmektedir. En az yedi kişi olması gereken katılımcılar ise kendi istekleri için dua etmektedirler. Balıkesir'in Dursunbey ilçesinde bu ritüel, "Acele Bacı Adamak” olarak bilinmektedir. Ritüel burada da dileğin gerçekleşmesinden sonra yapılmaktadır. Ritüelle ilgili bir derleme şu şekildedir: "Üç kişi üçerden dokuz Yasin okuyor. Bu dokuz Yasin, bir dilek gerçekleşmeden önce bir de gerçekleştikten sonra okunuyor. Yasinlerin biri Allah rızası için, biri peygamber efendimizin ruhuna, biri İmam-1 Azama, diğerleri de din büyüklerine adanıyor. Yedincisi de acele bacıya adanıyor. Dilek gerçekleşince az bir helva karılıyor. İnsanlara yediriliyor. Azıcık da kuşlara yediriliyor.” (Bıldır, 2008: 311)

2. Ritüelin düzenlendiği yer, esas itibariyle dileği gerçekleşen ya da gerçekleşmesini isteyen kişilerin evidir. Ancak başta Bursa (Acele Bacı'nın yatırının da burada olması sebebiyle) olmak üzere, helva dağıtımının yatırlar, medreseler, tekkeler çevresinde de gerçekleştirildiği görülmektedir. Örneğin Tarsus’ta ritüelin yapıldığı mekân, Giritli göçmenlerin uğrak yeri olan Horasanlı Ali Baba Tekkesi'dir. Ali Selçuk'un yaptığı bir derlemede Horasanlı Ali Baba'nın bir kadının rüyasına girerek, tekkesinde Acele Bacı yapmasını istediğine dair de bir söylenti yer almaktadır. Söylenti şu şekildedir: "Mübarek evliyamız birisinin rüyasına girmiş, demiş ki, ziyarete gideceksin acele bacı yapacaksın Kuran okuyacaksın ayna ve bir de güvercin getireceksin. Güvercini kafesle getirdi kadın, güvercin üç gün sonra uçtu gitti. Buradaki aynayı (ayna hâlâ duruyor) da kadın getirdi" (Selçuk, 2019: 33).

Ritüelde yer yer farklılaşmalar, değişmeler de olmuştur. Örneğin Bursa'da kadınlar, eskiden evinde kavurduğu helvayı Acele Bacı Türbesi etrafında dağıtırlarken günümüzde türbenin hemen yakınındaki helvacıdan alınan helvaların dağıtıldığı görülmektedir. Derlemelerde görüşülen kişiler bu durumun iki amaçla gerçekleştirildiğini söylemektedirler: İlki zamandan tasarruf etmek diğeri, "ambalajlı ürünlerin daha hijyenik olduğu” dair inanç (KK2).

3. Ritüelin zamanı: Yapılan derlemelerde ritüelin zamanı konusunda önemli bir hassasiyetin olduğu görülmektedir. Bu hassasiyette de cuma günü selâ ile ezan arasında yapılan tüm duaların kabul olacağı inanışının söz konusu olduğu belirlenmiştir. (KK1)

4. Ritüelin katılımcıları: Benzer bir hassasiyet bu ritüele katılan kişi sayısında görül- 
mektedir. Ritüele katılan kişilerin en az yedi kişi olması, görüşülen kişiler tarafindan Allah'ın tek olması ile açıklanmıştır. (KK1) Bu ritüelle ilgili bir kural da ritüele katılımın çok olmasının istenmesiyle ilgilidir. Katılımın çok olması durumunda "ağzı dualı, günahsız birinin” (KK1) duasını alma ihtimalinin daha fazla olması inancı bu ritüelin gerçekleşmesi için katılımcı sayısının en az yedi olarak belirlenmesine sebep olmuştur. Bu ritüelin yürütülmesi sırasında en önemli husus, ritüele katılan kimselerin temiz olmalarıdır. Katılımcıların kadınlardan oluşması sebebiyle bu ritüele katılanların adetli olmamaları da bir diğer kural olarak kaynak kişilerden derlenmiştir. (KK3)

\section{Ritüellerde kurbanın bir örneği olarak Acele Bacı helvası ritüelinde helva}

Kriz ritüellerinin bir örneği olarak değerlendirilebilecek Acele Bacı ile ilgili çözümlemelere geçmeden önce bu ritüel türü açıklanmalıdır. Kriz ritüelleri, yaşamın her hangi bir zamanında ortaya çıkan krizlerin yatıştırılması, bu durumun yarattığ lirsizlikten kurtulmak amacıyla gerçekleştirilen ritüeller olarak tanımlanabilir. Bir takvime bağlı olmayan bu ritüeller, krizin baş gösterdiği her zaman birey ya da toplum tarafından gerçekleştirilebilir. "Amaçların gerçekleştirilmesi durumunda, dünyanın normal düzenini bozan, kişi ve topluluk hayatını tehdit eden durumlarda" (Honko, 2006: 133) hastalıktan, yoksunluktan, kıtlıktan, uğursuzluktan deprem/sel gibi doğal afetlerden kurtulmak amaciyla bu ritüeller gerçekleştirilmektedir. Dileği olan kişilerin gerçekleştirdiği bir ritüel olan Acele Bacı Helvası ritüeli de bu bağlamda bir kriz ritüeli olarak ele alınmalıdır.

Ritüeller, mitolojik bir hikâyeyle desteklendiğinde, anlattığı ilk öykünün bir prototipini sunar. Mircea Eliade'nin belirttiği gibi "Bir ritüel, eğer 'kökeni, yani ilk olarak nasıl gerçekleştirildiğini anlatan mit bilinmiyorsa, yerine getirilemez” (Eliade, 2001: 27). Mitolojik öykünün amac1, sunulan ritüelin amacını oluşturur. Ritüel ve mitin ortaklığ belli başlı sacayaklarının birleşmesiyle ortaya çıkmaktadır. Kutsal mekân, kutsal zaman, kutsallığı onaylanan kişi ve kutsal yemek gibi.

Bir ritüelin en önemli bileşenlerinden biri olan yemeğin önemi konusunda Mehmet Ersal'ın şu tespitleri oldukça önemlidir:

Birçok ritüelin varlı̆̆ meydana gelen yemekler etrafinda şekillenmektedir. İnanç sisteminde icra edilen ritüellerde yiyecek ve içecekler yeni bir bağlam ve işlevde kutsalın bir parçası hatta kutsalın kendisi olarak karşımıza çıkmaktadır. Bu sebeple ortak inancin ritüelinde kutsal kişi, kutsal mekân ve kutsal zaman paylaşımında kutsalın aşamaları ile yemek olarak meydana gelen yiyecek ve içeceklerin doğrudan ilişkisi vardır. Yemek de ritüelin ortak paylaşılan, sir edilen, hazm edilen hatta "zevk edilen" bir parçasıdır (Ersal, 2017: 145).

Acele Bacı anlatısındaki sonuç; ritüelin gerçekleştirilme sebebini oluşturmaktadır. K1saca anlatıda Acele Bacı'nın bir evliya oluşu anlatının sonunda ortaya çıkarken, ritüelin ortaya çıkışı ifşa olan bu sır sebebiyledir. Bu sonucu ve başlangıcı bir birine bağlayan nesne ise helvadır. Helvayı, ritüellerde önemli bir unsur olan kurbanın bir örneği olarak okumak mümkündür. Bu çözümlemede doğum öncesi ritülleri ile başlayıp ölüm sonrası ritüellerinde bile yenilen tek besinin helva olduğu göz önünde bulundurulursa bu tatlının ölümle doğum birlikteliğinin bir ürünü olduğu kabul edilebilir. Helvanın sembolik değeri konusunda da şu bilgiler verilebilir: 
Her türlü acı ve sevinçli olaylar tatlı ile paylaşıllır. Acılar paylaşılıp azaltılır ve sevinçler paylaşılıp çoğaltılır. Ölümden sonra helva dağıtılması kadere razı olmayı, sevinçli olayların arkasından helva dağıtılması ise şükrü ve sevinci paylaşmayı sembolize etmektedir. Klsaca helva dağıtımı, bütün yönleriyle kaderin eş, dost, akraba ve komşuyla paylaşımını sembolize etmektedir (Tufan, 2008: 125).

$\mathrm{Bu}$ ritüelde helvayı kurbanın da bir örneği olarak kabul etmek gerekir. Bu noktada "Kurban /kurbanlıklar genellikle kanlı (canlı) ve kansız (cansı) olmak üzere iki türlüdür. Kansız kurbanlar insan, hayvan ve balıklar gibi canlı varlıkların dışında Tanrılara sunulan diğer hediyeleri kapsar. Bu hediyeler insanların sahip oldukları ve üretebildikleri her türlü gıda maddesi nevinden şeylerdir” (Bekki, 1996: 20). Kansız kurban saçı olarak da adlandırılmaktadır. Abdulkadir İnan, saçı kavramını şu şekilde açıklamaktadır:

Saçı her kavmin kendi emeğiyle kazandığı en klymetli ve mübarek saydiğı nimetlerden biri olur. Göçebe kavimlerde süt, kımız, yă̆; çiftçi kavimlerde buğday, darı, şarap; tüccar kavimlerde para vesaire saçı olarak kullanılır. Ruhlara saçı yapma âdeti, dini telakkilerin muayyen bir safhasında bütün dünya kavimlerinde yalnız görenek olarak son zamanlara kadar devam ettiği malumdur. Biri hakkında hayırlı bir haber söylerken 'darısı başımıza!' temennisi işte bu eski adetten kalma bir hatıradir (İnan, 2000: 100).

Çeşitli türbe, yatır ve ziyaret yerlerinde sıklıkla görülen mum, kumaş parçaları, şeker, helva gibi unsurları saçının bir örneği olarak ele almak mümkündür. Abdurrahim Tufantoz'un yaptığı bir alıntıda da Bektaşi ve Alevi Türklerinde pişi ve helva pişirmenin yani yağ kokutmanın cansız kurban olarak adlandırıldığından bahsedilmektedir (Tufantoz, 2008: 72). Aynı makalede Tufantoz, özel günlerde yapılan pişi ya da helva pişirmenin (yağ kokutma, yağ yakma, koku çıkartma geleneklerinin) atalar kültüyle ilgili olduğunu söylemektedir. (Tufantoz, 2008: 72). Bu konuyla ilgili yapılan bir derlemede, uygulamanın temelinde "kokusuyla melaikelerin, tavasıyla insanların doyduğu" inancının hâkim olduğu sonucuna ulaşmaktadır (Tufantoz, 2008: 72).

$\mathrm{Bu}$ ritüelde evin çatısı, balkonu gibi bir bölüme kurdun kuşun hakkı olarak bir parça helva konulması, çok detay bir eylem olarak görülse de ritüelin amacını doğrudan açığa çıkaran bir uygulamadır. Benzer bir uygulamayı pek çok ritüelde de görmek mümkündür. Tufantoz'un Refik Engin'den yaptığı alıntıda ritüllerde hazırlanan pişi ve helvaların öncelikle çocuklara verilmesi geleneğinin devam ettiğini, bu uygulamanın temelinde çocukların masum olmalarından dolayı dualarının kabul olacağı inancının yattığı belirtilmektedir (Tufantoz, 2008: 72).

\section{Acele Bacı helvası ritüelinin işlevleri}

Ritüellerin işlevleri, özellikle kendisine bağlı olarak anlatılan mitlerin/efsanelerin işbirliğinde ortaya çıkmaktadır. Bu anlatılar ritüellerle birleştiklerinde katılımcılarına adeta yol gösterici olurlar. İşlevsel halkbilim kuramının öncü isimlerinden biri olan antropolog Bascom (2010: 71-86) 1954 yılında "The Journal of American Folklore" dergisinde yayımlanan makalesinde folklorun dört işlevi olduğundan söz etmektedir. Bunlar:

1. Hoşça vakit geçirme ve eğlenme işlevi

2. İnançlara, değerlere ve törelere destek verme işlevi 
3. Kültürü gelecek kuşaklara aktarma ve eğitim işlevi

4. Toplumsal ve kişisel baskılardan kurtulma işlevi (Bascom, 2010: 139-141).

Durkheim ise ritüelin toplumsal işlevleri konusuna ilk değinen araştırmacıdır. Onun belirlediği işlevler şu şekildedir:

“1) Ritüel, bireyi toplumda yaşamak için toplumun gerektirdiği düzen bağının sıkılığına, acı çekmeye hazırlar, bu yolda onu eğitir.

2) Ritüel, bireyleri bir araya getirir, bireyler arasındaki toplumsal bağları güçlendirir, ortaklığı pekiştirir.

3) Ritüelin toplumda canlandırıcı bir işlevi vardır. Toplumun ilişkilerini kalıtlarının bilincine vardırır; geleneklerin sürmesine, inançların tazelenmesine, değer yargılarının, törelerin kökleşmesine yardım ederek toplumu canlı bir biçimde ayakta tutar.

4) Mutluluk verici işlev: Toplumun bir üyesi olmanın getirdiği mutluluk duygusunu verir. Özellikle toplumun bunalımlı dönemlerinde kişilerin coşku ve duygularını bir arada dile getirmelerine olanak tanıyarak bozulan dengeyi düzeltir" (And, 2003: 307).

Özkul Çobanoğlu da Durkheim'ın ve Bascom'ın işlevle ilgili çalışmalarından hareketle Nevruz ve Hıdrellezin sahip oldukları temel işlevleri birleştirici işlev, canlandırıcı işlev, eğitici işlev ve mutluluk verici (rahatlatıcı) işlev olarak dört başlık altında inceler (Çobanoğlu, 2000: 57). Çobanoğlu'nun belirlediği bu işlevlerin Acele Bacı helvası ritüeline de uygulanması mümkündür.

Acele Bacı Helvası ritüelinde temel amaç, isteğin gerçekleşmesidir. Bu isteğin gerçekleşmesi esnasında kadınlar arasında bir dayanışmanın olduğu görülmektedir. En az yedi kadının bu ritüel esnasında aynı amaç için toplanması ile mitik bir anlatının, bu ritüel ve efsane etrafında şekillenen değer yargılarının yeniden canlandırılması sağlanmaktadır. Bu bağlamda Bascom'un mitin işlevi olarak gördüğü “ $O$ inançları tanımlar, düzenler ve değerlerini arttırır; o ahlakı korur ve uygulanmasını sağlar; o ritüellerin etkilerini doğrular ve yol göstericiler için pratik kuralları içerir" (Bascom, 2010: 140) tespitleri doğrultusunda Acele Bacı ile ilgili efsanelerin yayılması ile (özellikle internette insanların birbirlerine bu ritüeli tavsiye etmeleriyle) ritüelin daha fazla kişi tarafından uygulandığ 1 görülmektedir. Efsanenin hitap ettiği çevrenin artışıyla da ritüel özellikle kadınlar arasında canlılığını arttırarak devam etmektedir.

Ayrıca efsaneye olan inancın sağlam bir şekilde varlığını sürdürmesi ve ritüelle ilgili bir takım yasaklamalara ve kısıtlamalara uyulması ritüelin eğitici yanını ortaya koymaktadır. Ritüeli gerçekleştiren bireylerin isteklerinin gerçekleşmesi konusunda nasıl davranmaları gerektiğiyle ilgili bilgilere sahip olmaları ve bu konuyla ilgili geleneğin sonraki nesillere de aktarımı sağlanmaktadır. Bascom, ritüel katılımcıları için mitolojik anlatıların önemli bir eğitici olduğunu söylerken sözlerine şu şekilde devam etmektedir: “Törene katılanlar orada bulunan talimatlar doğrultusunda töreni gerçekleştirmektedir. Onların eğitim sistemi mitolojik sistemlerdir, çocuklar gece masalları dinlemek için oturarak geleneksel bilgileri öğrenirler ve bizim altı kişilik modern sınıflarımızdakinden daha farklı davranmazlar" (Bascom, 2010: 141).

Bir dinî anlatıyla perçinlenmesi ritüele olan inancı sağlamlaştırırken aynı zamanda bireylerin geleceğe olan beklentilerini de arttırmaktadır. Bireylerin Acele Bacı adı verilen bu evliya aracılığıyla sıkıntılarının giderileceğine ve geleceklerinin güvence altında olacağına dair umut verir. Bascom'un ifadesiyle "günlük yaşamın zorluklarından, eşitsizliklerinden ve adaletsizliklerinden telafi edici bir kaçış sağlamak” için kullanılan folklorun bir unsuru olan ritüeller/ Acele 
Bacı Helvası ritüeli, günlük yaşamdaki bireye yalnız olmadığının bilgisini verirken, yaşadığı zorluklardan bir kaçışın yolunu sunmaktadır. Böylece ritüel, kaotik bir dünyada çaresizlik içinde kıvranan bireylere dini yönü ağır basan bir karakter aracılığıyla umut vaat etmektedir.

\section{Sonuç}

Efsaneler, toplumun değer yargılarını, inançlarını, etik ilkelerini içerisinde barındıran sözlü anlatılardır. Onu diğer türlerden ayıran en önemli özelliği; inanılır, kabul edilir olmasıdır. Nesilden nesile anlatılarak varlığını sürdüren efsaneler, ritüellerle birleştiğinde bu özelliğinden dolayı ritüelin etkisini arttırıcı, ritüeli canlandırıcı bir etkiye sahiptir.

Türkiye'de derlenen efsane motiflerinden biri Hacca Giden Ağasına Helva Götürme Motifi'dir. Çeşitli eş metinleri olan bu efsanenin en önemlilerinden biri de Acele Bacı ile ilgili anlatıdır. Bu efsane, Türkiye'nin pek çok ilinde Acele Bacı Helvası, Acele Bacı Adamak gibi ritüellerle de etki alanını genişletmiştir. Makalede, Acele Bacı Helvası ritüelleri yaşamın her hangi bir zamanında ortaya çıkan krizlerin yatıştırılması, bu durumun yarattığı huzursuzluktan ve belirsizlikten kurtulmak amaciyla gerçekleştirdiği için Lauri Honko’nun ritüel sınıflandırmasına göre kriz ritüelleri kategorisinde ele alınmıştır.

Makalede ayrıca bu ritüel, Özkul Çobanoğlu'nun Hıdırellez ve Nevruz bayramlarını incelemek üzere ortaya koyduğu dört işlev kapsamında incelenmiştir. Çobanoğlu'nun birleştirici işlev, canlandırıcı işlev, eğitici işlev ve mutluluk verici (rahatlatıcı) işlev olarak sınıflandırdığı işlevlerin Acele Bacı Helvası ritüellerine de uygun olduğu makaleden çıkarılabilecek bir sonuçtur.

\section{Notlar}

1 Gennep, önemli eserini Durkheim'den yalnızca üç sene önce yayımlamış olmasına rağmen Durkheim'de kesinlikle kendisinden bahsedilmez. Benzer şekilde Gennep'in çalışmasında da Durkheim'den bahsedilmemektedir. Bu konu hakkında daha fazla bilgi için bknz (Honko, 2006: 129).

2 Örneğin Robert A. Segal bu konu hakkında Radcliffe-Brown’un efsanelerle mitleri dönüşümlü kullandığının altını çizer (Segal, 2012: 181).

3 Bu fotoğraf https://www.yenimarmaragazetesi.com/helvaci-baci-kimdir--147774.html isimli siteden alınmıştır.

4 Bu fotoğraf https://www.yenimarmaragazetesi.com/helvaci-baci-kimdir--147774.html isimli siteden alınmıştır.

5 Bascom'un dört maddede belirttiği folklorun dört işlevine beşinci bir madde olarak İlhan Başgöz'ün "Protesto İşlevi”ni de eklemeliyiz.

\section{Kaynaklar}

Akın, B. (2017). Alevi Cem ritüellerinin sınıflandırılması sorunu ve yeni bir sınıflandırma önerisi. 9. Milletlerarası Türk Halk Kültürü Kongresi. Ordu.

Alptekin, A. B. (2012). Efsane ve motifleri üzerine. (3. bs.). Ankara: Akçağ.

And, M. (2003). Oyun ve bügü Türk kültüründe oyun kavramı. İstanbul: Yap1 Kredi.

And, M. (2008). Minyatürlerle Osmanlı-İslâm mitologyası. (2. bs).(S. Koz, Ed.). İstanbul: Yap1 Kredi. Bekki, S. (1996). Türk mitolojisi’nde kurban. Akademik Araştırmalar. Y. I. S. 3. ss. 16-28.

Bıldır, F. (2008). Dursunbey (Ballkesir) yöresi halk edebiyatı ve folklor ürünleri üzerine bir araştırma. Yayımlanmamış Yüksek Lisans Tezi. Balıkesir Üniversitesi Sosyal Bilimler Enstitüsü Türk Dili ve Edebiyatı Anabilim Dalı. Balıkesir. 
Bascom, W. R. (2010). Folklorun dört işlevi. (F. Çalış, Çev.). Halkbiliminde kuramlar ve yaklaşımlar 2. (M. Ö. Oğuz vd. Ed.) Ankara: Geleneksel. 71-86.

Bayat, F. (2010). Mitolojiye giriş. İstanbul: Ötüken.

Campbell, J. (1995). İlkel mitoloji tanrının maskeleri. (2. bs.). (K. Emiroğlu, Çev.). İstanbul: İmge

Çobanoğlu, Özkul. (2000). Yapısal ve işlevsel bakımdan geleneksel bayramlar bağlamında nevruz ve hıdrellez. Türkbilig HÜ Türkoloji Araştırmaları Dergisi. S.1. ss. 51-59.

Durkheim, E. (2005). Dini hayatın ilkel biçimleri. Ataç.

Eliade, M. (2001). Mitlerin özellikleri. (S. Rifat, Çev.). İstanbul: Om.

Ersal, M. ve Görgülü, E. D. (2017). Yemekten ritüel yaratmak: Alevi inanç sisteminde yemek kültü. Alevilik-Bektaşilik Araştırmaları Dergisi 16.

Gönen, S. (2007). Tayyimekân ve tayyizaman bağlamında Ladikli Ahmet Ağa ile ilgili efsanelerin çözümlenmesi. Millî Folklor. Y. 19, S. 76.

Honko, L. (2006). Ritüellerin oluşum süreci. (R. Ersoy, Çev.) Millî Folklor. Y.18, S. 69.

İnan, A. (2000). Tarihte ve bugün Şamanizm materyaller ve araştırmalar. Ankara: Türk Tarih Kurumu.

Ozan, M. (2011). Geçiş ritüelleri ve halk masalları. Millî Folklor. Y. 23, S. 91.

Ögel, B. (2010). Türk Mitolojisi. Türk Tarih Kurumu. (1. cilt, 5. bs.) Ankara.

Sakaoğlu, S. (1997). Bir efsane, iki tip, bir motif: Şeyh Bilecen ve Memik Dede efsaneleri. Türkiyat Araştırmaları Dergisi. Konya. S. 4. ss. 181-190.

Segal, R. A. (2012). Dinsel mit-ritüel kuram. (N. Atabağsoy, Çev.), Millî Folklor. Y. 24, S. 94.

Selçuk, A. (2019). Giritli Bektaşilerde ziyaret ritüeli: Horasanlı Ali Baba tekkesi. Ordu Üniversitesi Sosyal Bilimler Araştırmaları Dergisi. S. 9(1). ss. 29-35.

Tufan, Ö. (2008). Helvahane ve Osmanlı helva kültürü. Türk Mutfă̆g. (A. Bilgin, Özge Samanc1, Ed.). (ss. 125-135). Ankara: Kültür Bakanlığı.

Tufantoz, Abdurrahim, (2008). Orta Asya'dan Balkanlar'a Türklerde pişi ve helva pişirme geleneği. Türk Kültürü ve Hacı Bektaş Velî Araştırma Dergisi. S. 45.

\section{Kaynak kişiler}

KK1: Kadir Soyeri, 1964, İlahiyat Fakültesi, Trabzon, İmam.

KK2: Arif Demir, Bursa/ İnegöl, 1949, Ortaokul/ Bursa İnegöl.

KK3: Hayriye Şahin, 1964,Ortaokul, Silifke/Atayurt, Ev hanımı. 